\title{
Corrosion Inhibition of Aluminium with A Series of Aniline Monomeric Surfactant and Their Analogues Polymers in 0.5 M HCl Solution Part I: 3-(6- Sodiumsulfonate hexayloxy) Aniline Monomeric Surfactant $\left(\mathrm{MC}_{6}\right)$ and Its Analogues Polymer
}

\author{
S.M. Sayyah", S.S. Abd El-Rehim*, M.M. El-Deeb and S.M. \\ Mohamed \\ Polymer Research Lab., Chemistry Department, Faculty of \\ Science, Beni Suef University 62514 Beni Suef and *Chemistry \\ Department, Faculty of Science, Ain Shams University, Cairo, \\ Egypt.
}

\begin{abstract}
THE INHIBITION effect of 3-(6- sodiumsulfonate hexayloxy) aniline monomeric surfactant $\left(\mathrm{MC}_{6}\right)$ and the analogues polymer poly 3-(hexayloxy sulphonic acid) aniline $\left(\mathrm{PC}_{6}\right)$ on the corrosion of aluminium in $0.5 \mathrm{M} \mathrm{HCl}$ solution was investigated with weight loss and potentiodynamic polarization techniques. The results show that the inhibition occurred through the adsorption of inhibitor molecules on the metal surface. The inhibition efficiency was found to increase with increasing of inhibitor concentration and decrease with increasing temperature. It was found that these inhibitors acted as mixed-type inhibitors with anodic predominance. The adsorption of these compounds on the metal surface obeyed the Langmuir and Frumkin adsorption isotherms. Thermodynamic functions for both the dissolution and adsorption processes were determined. The obtained results from weight loss and potentiodynamic polarization techniques are in good agreement.
\end{abstract}

Keywords: Activation energy, Adsorption, Conducting polymers, Electro-chemistry and Surfactants .

Aluminium has a remarkable economic and industrial importance owing to its low cost, light weight, high thermal and electrical conductivity. The most important feature of aluminium is its corrosion resistance due to the formation of a protective film on its surface upon its exposure to atmosphere or water ${ }^{(1)}$. Several authors ${ }^{(2-4)}$ have studied the corrosion of aluminium and its inhibition by organic inhibitors in acid solutions. Various surfactants as well as 1, 1-(laurly amido) propyl ammonium chloride are being studied as a corrosion inhibitor for pure aluminium in acid media ${ }^{(5-6)}$. Many of organic compounds as electroactiveconducting polymers ${ }^{(7-15)}$, carboxylic organic acids ${ }^{(16,17)}$, fatty acids (18) dicyandiamide and some of its related compounds ${ }^{(19)}$, triazole and thiazole derivatives ${ }^{(20,21)}$, were also found to inhibit the corrosion of aluminium.

\#Correspondance to: smsayyah@hotmail.com 
The inhibition of most of these compounds occurs via their adsorption on the metal surfaces which can markedly change the corrosion - resisting property of the metal ${ }^{(22,23)}$ and thus the study of the relations between the adsorption and corrosion inhibition is of a great importance.

Abd El-Rehim et $a l^{(24)}$ studied the effect of sodium dodecyl benzene sulphonate on the corrosion of aluminium and its alloy in $1 \mathrm{M} \mathrm{HCl}$. The data show that the addition of this surfactant inhibits the hydrochloric acid corrosion of the aluminium samples and the inhibition occurs through adsorption of the surfactant on the metal surface and fits Frumkin adsorption isotherm.

The objective of this study is to investigate the corrosion inhibition performance of 3-(6-sodiumsulfonate hexayloxy) aniline $\left(\mathrm{MC}_{6}\right)$ and its analogues polymer $\left(\mathrm{PC}_{6}\right)$ as mixed-type inhibitors in $0.5 \mathrm{M} \mathrm{HCl}$ solution. This performance will be investigated via weight loss measurements and potentiodynamic polarization techniques. In addition, this work will extend to compare the experimental data obtained from weight loss and potentiodynamic polarization technique with several adsorption isotherms at different temperatures in order to determine the thermodynamic functions for the adsorption process and to get more information about the mode of adsorption of the inhibitors on the surface of aluminium.

\section{Materials}

\section{Experimental}

3-Aminophenol provided by Aldrich Chemical Co. Sodium sulfite used in the synthetic process was obtained from Merck Chemical Co., (Germany). Concentrated hydrochloric acid was chemically pure grade products provided by Prolabo-Chemical Co., (U.K.). Double distilled water was used as a medium for the polymerization reactions. Potassium persulfate , 3 -aminophenol and 1,6dibromohexane were obtained from Aldrich Chemical Co., England.

\section{Weight loss measurements}

Aluminium metal was provided by the Egyptian Aluminium Company , NagHammady, Egypt with the following chemical composition: $99.57 \% \mathrm{Al}, 0.31 \%$ $\mathrm{Fe}, 0.07 \% \mathrm{Si}, 0.015 \% \mathrm{Ti}, 0.0016 \% \mathrm{Zn}, 0.0003 \% \mathrm{Cr}, 0.0019 \% \mathrm{Mg}$, $0.0021 \% \mathrm{Mn}$ and $0.0007 \% \mathrm{Cu}$. The dimensions of the tested samples were $2 \mathrm{x}$ $2 \times 0.1(\mathrm{~cm})$. The samples were polished successively with fine grade emery papers, cleaned with acetone, washed with doubly distilled water and finally dried, weighed and then introduced into test solution.

\section{Potentiodynamic polarization measurements}

The working electrode was made from $\mathrm{Al}$ rod that has the same composition as mentioned above. The rod was axially embedded in araldite holder to offer an active flat disc shaped surface of an area of $0.785 \mathrm{~cm}^{2}$. Before each experiment, the working electrode was polished successively with fine emery paper. The polished metal surface was rinsed with acetone and distilled water before dipping

Egypt. J. Chem. 55, No.6 (2012) 
it into the electrolytic cell. A platinum wire was used as the counter electrode and a saturated calomel electrode as a reference electrode to which all potentials are referred.

The electrochemical experiments were performed with Wenking PGS95, Potentiostat /Galvanostat connected to a computer. The current potential curves (I-E) were recorded with computer software (ECT). The experiments were carried out by changing the electrode potential automatically from the starting potential towards more positive values at the required scan rate till the end of the experiments.

Synthesis of monomeric 3-(6- sodiumsulfonate hexayloxy) aniline $\left(M C_{6}\right)$

3-( 6- Bromohexayloxy) aniline monomeric surfactant was prepared by an equimolar reaction, between 3 -aminophenol with 1-(6-dibromohexane), in the presence of sodium ethoxide. The product 3-(6-bromohexayloxy) aniline was reacted with sodium sulfite to produce $\mathrm{MC}_{6}$ as mentioned by Sayyah et al. ${ }^{(25)}$.

Synthesis of polymeric 3-(hexayloxy sulphonic acid) aniline $\left(P C_{6}\right)$

Poly 3-(hexayloxy sulphonic acid) aniline was synthesized by dissolving $0.1 \mathrm{M}$ of 3-(6- sodiumsulfonate hexayloxy) aniline in $25 \mathrm{ml}$ of $2.0 \mathrm{M} \mathrm{HCl}$ solution into a well stoppered conical flask $250 \mathrm{ml}$ capacity, followed by the addition of $0.3 \mathrm{M}$ potassium persulfate $(25 \mathrm{ml})$ to the reaction mixture under nitrogen atmosphere. The order of addition of substances was kept constant in the performed experiment. The stoppered conical flask was then placed in an automatically controlled thermostat at $25^{\circ} \mathrm{C}$. The flask was shaken $(50$ shakings/10 s/15 min) for one hour with an automatic shaker, left for $72 \mathrm{hr}$ at room temperature to continue the reaction and then filtrated with a Buchner funnel. The solid was washed with the distilled water and finally dried in vacuum at room temperature until a constant weight was reached.

\section{Elemental and spectroscopic analysis}

The elemental analysis of the prepared monomeric surfactant $\left(\mathrm{MC}_{6}\right)$ and its analogues polymer $\left(\mathrm{PC}_{6}\right)$ was carried out in the Microanalytical Laboratory at Cairo University with oxygen flask combustion and a dosimat E415 titirator (Switzerland). The data are summarized in Table 1, which show that there was a good agreement between the calculated structure and suggested structure present in Scheme 1. The number of water molecules in the polymer unit was calculated as mentioned by Sayyah. et al. ${ }^{(26)}$.

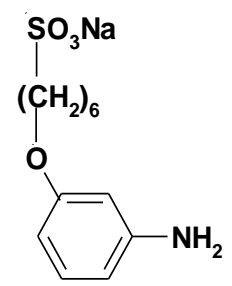

\section{A: 3-(6-Sodiumsulfonate hexayloxy) aniline $\left(\mathrm{MC}_{6}\right)$}

Egypt. J. Chem. 55, No.6 (2012) 


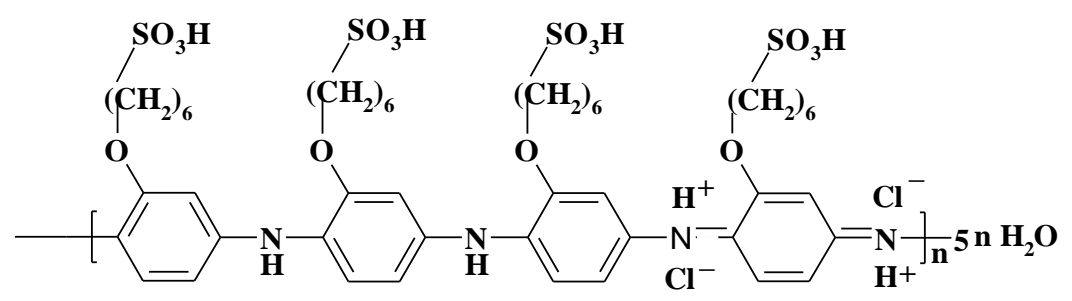

B: Poly 3-( hexayloxy sulphonic acid) aniline $\left(\mathrm{PC}_{6}\right)$

Scheme 1. Structure of monomeric surfactant (A) and its analogues polymer(B).

TABLE 1. Elemental analysis of the prepared monomeric surfactant $\left(\mathrm{MC}_{6}\right)$ and its polymer( $\left.\mathrm{PC}_{6}\right)$.

\begin{tabular}{ccccccccccccc}
\hline \multirow{2}{*}{ Name } & \multicolumn{2}{c}{$\mathrm{C} \%$} & \multicolumn{2}{c}{$\mathrm{H} \%$} & \multicolumn{2}{c}{$\mathrm{Cl} \%$} & \multicolumn{2}{c}{$\mathrm{S} \%$} & \multicolumn{2}{c}{$\mathrm{N} \%$} & \multicolumn{2}{c}{$\mathrm{N} \mathrm{a} \%$} \\
\cline { 2 - 12 } & Calc. & Found & Calc. & Found & Calc. & Found & Calc. & Found & Calc. & Found & Calc. Found \\
\hline $\mathrm{MC}_{6}$ & 48.80 & 48.12 & 6.14 & 5.99 & - & - & 10.85 & 10.65 & 4.74 & 4.58 & 7.78 & 7.63 \\
$\mathrm{PC}_{6}$ & 46.26 & 46.92 & 6.26 & 6.54 & 5.70 & 5.75 & 10.28 & 10.36 & 4.49 & 4.53 & - & - \\
\hline
\end{tabular}

The infrared (IR) spectroscopic analysis of the prepared monomeric and polymeric surfactants was carried out in the Micro analytical Laboratory at Cairo University with a Jasco FTIR-430 Spectrophotometer and potassium bromide disc techniques. The IR absorption bands and their assignments ${ }^{(27)}$ of $\mathrm{MC}_{6}$ and $\mathrm{PC}_{6}$ are summarized in Table 2. The medium absorption band appearing at $409 \mathrm{~cm}^{-1}$ which could be attributed to bending deformation of $\mathrm{N}-\mathrm{H}$ group attached to the benzene ring in case of monomer, appearing at $500 \mathrm{~cm}^{-1}$ with slight shift in case of polymer. The strong absorption band appearing at $626 \mathrm{~cm}^{-1}$ which could be attributed to out-of-plane deformation of $\mathrm{CH}$ for 1,3disubstituted benzene ring in case of monomer but disappears in case of polymer. The medium absorption band appearing at $755 \mathrm{~cm}^{-1}$ in case of monomer due to the rocking deformation of methylene group in case of monomer, appears also with slight shift at $750 \mathrm{~cm}^{-1}$ in case of polymer. The sharp absorption band appearing at $972 \mathrm{~cm}^{-1}$ which could be attributed to symmetric stretching vibration of $\mathrm{S}-\mathrm{O}$ or $\mathrm{C}-\mathrm{N}$ group in case of monomer appears at $917 \mathrm{~cm}^{-1}$ as a medium band in case of polymer. A series of absorption bands appearing in the region from 1000 to $1200 \mathrm{~cm}^{-1}$ could be attributed to symmetric stretching vibration for $\mathrm{C}-\mathrm{O}$ group in case of both monomer and its analogues polymer. The sharp absorption band appearing at $1408 \mathrm{~cm}^{-1}$ which could be attributed to scissoring deformation of $\mathrm{CH}$ in methylene group in case of monomer, appears at $1457 \mathrm{~cm}^{-1}$ in case of polymer. The medium absorption band appearing at $1545 \mathrm{~cm}^{-1}$ which could be due to symmetric stretching vibration of $\mathrm{C}=\mathrm{C}$ in quinoide structure in benzene ring, disappears in case of monomer. The broad absorption band appearing at $1624 \mathrm{~cm}^{-1}$ which could be attributed to symmetric stretching vibration of $\mathrm{C}=\mathrm{C}$ in case of monomer, appears as splited band at Egypt. J. Chem. 55, No.6 (2012) 
1616 and $1639 \mathrm{~cm}^{-1}$ in case of polymer. The shoulder absorption band appearing at $2930 \mathrm{~cm}^{-1}$ may be due to asymmetric stretching vibration for $\mathrm{CH}$ group in aliphatic chain in case of monomer, appears as a medium absorption band at $2928 \mathrm{~cm}^{-1}$ in case of polymer. The broad absorption band appearing at $3163 \mathrm{~cm}^{-1}$ in case of monomer for the stretching vibration of hydrogen bonded $\mathrm{OH}$ group in sulphonic group, appears as a medium absorption band at $3235 \mathrm{~cm}^{-1}$ in case of polymer. Other absorption bands and their assignments are summarized in Table 2.

TABLE 2. Infrared absorption bands and their assignments in case of monomeric surfactant and its polymer.

\begin{tabular}{|c|c|c|}
\hline \multicolumn{2}{|c|}{$\begin{array}{c}\text { Wave number } \\
\left(\mathrm{cm}^{-1}\right)\end{array}$} & \multirow[t]{2}{*}{ Assignments $^{(26)}$} \\
\hline $\mathbf{M C}_{6}$ & $\mathbf{P C}_{6}$ & \\
\hline $409^{\mathrm{m}}$ & $500^{\mathrm{m}}$ & Bending deformation of $\mathrm{NH}$ in primary aromatic amines \\
\hline $626^{\mathrm{s}}$ & --- & $\begin{array}{l}\text { Out-of-plane bending deformation of } \mathrm{CH} \text { in 1,3-disubstituted } \\
\text { benzene ring. }\end{array}$ \\
\hline $755^{\mathrm{m}}$ & $750^{\mathrm{m}}$ & In-plane rocking vibration for $\mathrm{CH}$ in aliphatic chain \\
\hline--- & $816^{\mathrm{s}}$ & $\begin{array}{l}\text { Out-of-plane bending deformation of } \mathrm{CH} \text { in 1,3,4-trisubstituted } \\
\text { benzene ring. }\end{array}$ \\
\hline $972^{\mathrm{s}}$ & $917^{\mathrm{m}}$ & Symmetric stretching vibration for S-O or C-N group \\
\hline $1056^{\mathrm{m}}$ & - & \multirow{3}{*}{ Symmetric stretching vibration for C-O group } \\
\hline $1131^{\mathrm{m}}$ & $1136^{\mathrm{m}}$ & \\
\hline- & $1197^{\mathrm{m}}$ & \\
\hline $1328^{\mathrm{w}}$ & $1321^{\mathrm{w}}$ & Symmetric stretching vibration for $\mathrm{S}=\mathrm{O}$ group \\
\hline $1408^{\mathrm{s}}$ & $1457^{\mathrm{w}}$ & Scissoring deformation for $\mathrm{CH}$ in methylene group \\
\hline--- & $1545^{\mathrm{m}}$ & Stretching vibration for quinoide structure in benzene ring \\
\hline $1624^{\mathrm{b}}$ & $\begin{array}{l}1616^{2} \\
1639^{\mathrm{m}} \\
\end{array}$ & Stretching vibration for $\mathrm{C}=\mathrm{C}$ in benzene ring \\
\hline $2853^{\text {sh }}$ & $2845^{\mathrm{w}}$ & Symmetric stretching vibration for $\mathrm{CH}$ group in aliphatic chain \\
\hline $2930^{\text {sh }}$ & $2924^{\mathrm{m}}$ & Asymmetric stretching vibration for $\mathrm{CH}$ group in aliphatic chain \\
\hline $3041^{\text {sh }}$ & $3040^{\text {sh }}$ & symmetric stretching vibration for $\mathrm{CH}$ group in benzene ring \\
\hline $3163^{\mathrm{b}}$ & $3235^{\mathrm{m}}$ & $\begin{array}{l}\text { Stretching vibration for } \mathrm{OH} \text { group in } \mathrm{SO}_{3} \mathrm{H} \text { group strongly hydrogen } \\
\text { bond }\end{array}$ \\
\hline $3414^{\mathrm{m}}$ & --- & Symmetric stretching vibration for $\mathrm{NH}$ in aromatic amine \\
\hline $3446^{\text {sh }}$ & $3479^{\mathrm{m}}$ & Asymmetric stretching vibration for $\mathrm{NH}$ in aromatic amine \\
\hline sharp & & $\mathrm{sh}=$ shoulder \\
\hline
\end{tabular}

Egypt. J. Chem. 55, No.6 (2012) 
Critical micelle concentration and contact angle

Critical micelle concentration (CMC) and contact angle were measured by using K100 Tensiometer (Kruss Type) for the hydrochloric form of synthesized monomeric and polymeric surfactants using different concentrations.

\section{Results and Discussion}

\section{Weight loss measurements}

Figure 1 represents the straight line relation of the weight loss (in $\mathrm{mg} . \mathrm{cm}^{-2}$ ) as a function of the immersion time for aluminium in $0.5 \mathrm{M} \mathrm{HCl}$ solution in the absence and presence of different concentrations of 3-(6- sodiumsulfonate hexayloxy) aniline $\left(\mathrm{MC}_{6}\right)$ monomeric surfactant and its polymer $\left(\mathrm{PC}_{6}\right)$ at $30^{\circ} \mathrm{C}$. The slope of each line $\left(\mathrm{mg} . \mathrm{cm}^{-2} \mathrm{~min}^{-1}\right)$ represents the corrosion rate of aluminium at the specified conditions. From these data, the weight loss and hence rate of corrosion of aluminium enhances with the immersion time. On one hand, the dissolution of aluminium in $\mathrm{HCl}$ solution is slow and increases with the immersion time as indicated by increasing the weight loss by time, this may be due to the presence of a pre-immersion hydrate $\mathrm{Al}_{2} \mathrm{O}_{3}$ film on the metal surface ${ }^{(28)}$. On the other hand, the addition of $\left(\mathrm{MC}_{6}\right)$ monomeric surfactant and its polymer $\left(\mathrm{PC}_{6}\right)$ retards the rate of dissolution and inhibits the acid corrosion of aluminium. The inhibition efficiency values $(\mathrm{P} \%)$ at different inhibitor concentrations and temperatures were calculated from the following equation (1):

$$
\mathbf{P} \%=100 x\left(1-\frac{W}{w_{0}}\right)
$$

where $\mathrm{W}_{0}$ and $\mathrm{W}$ are the weight losses per unit of time in the absence and presence of the inhibitors, respectively. The data are summarized in Table 3. As shown from Table 3, the inhibition efficiency of $\mathrm{PC}_{6}$ was higher than that of $\mathrm{MC}_{6}$. The inhibition efficiency increased with increasing concentration of the two surfactants and reached a maximum value at a critical concentration $(8.47 \mathrm{x}$ $10^{-5} \mathrm{~mol} / \mathrm{L}$ in case of $\mathrm{MC}_{6}$ and $4.11 \times 10^{-6} \mathrm{~mol} / \mathrm{L}$ in case of $\mathrm{PC}_{6}$ ). Beyond this critical concentration, the efficiency tended to achieve steady state values. It was observed that, the maximum efficiency was obtained at concentration lower than the respective critical micelle concentration $\left(5 \times 10^{-4} \mathrm{~mol} / \mathrm{L}\right.$ for $\mathrm{MC}_{6}$ and $2.3 \times 10^{-4} \mathrm{~mol} / \mathrm{L}$ for $\mathrm{PC}_{6}$ ). This means that, the adsorption of these surfactants on $\mathrm{Al}$ surface reached equilibrium before the formation of micelles (The aggregation of these surfactant long chains into fairly large charged units).

The contact angle is the angle formed when a liquid droplet is placed on the solid surface and its values vary from $0^{\circ}$ (perfect wetting) to $180^{\circ}$ (complete nonwetting). The values of the contact angle for $\mathrm{MC}_{6}$ and $\mathrm{PC}_{6}$ at $30^{\circ} \mathrm{C}$ are given in Table 3. The data clearly show that, the inhibition efficiency of these two inhibitors increased with the decrease in their contact angles. Moreover, it was observed that the contact angles for $\mathrm{PC}_{6}$ were lower than that for $\mathrm{MC}_{6}$ in all of the investigated concentration. This confirmed that $\mathrm{PC}_{6}$ was more effective than $\mathrm{MC}_{6}$ in inhibiting the acid corrosion of $\mathrm{Al}$.

Egypt. J. Chem. 55, No.6 (2012) 


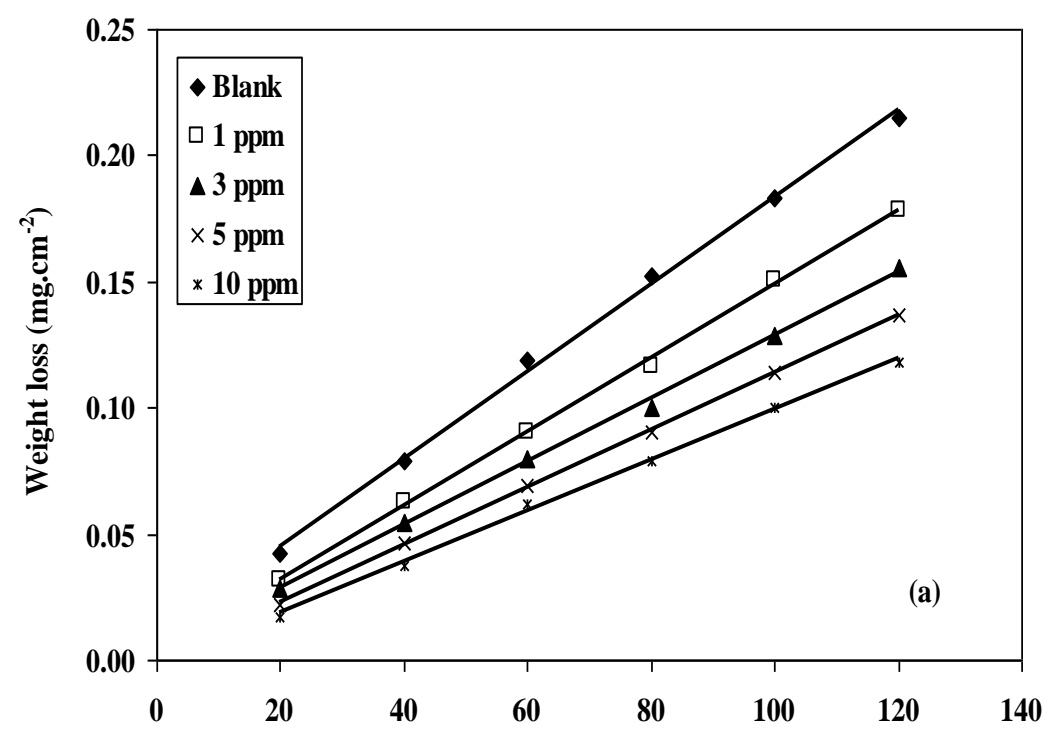

Time of immersion, min.

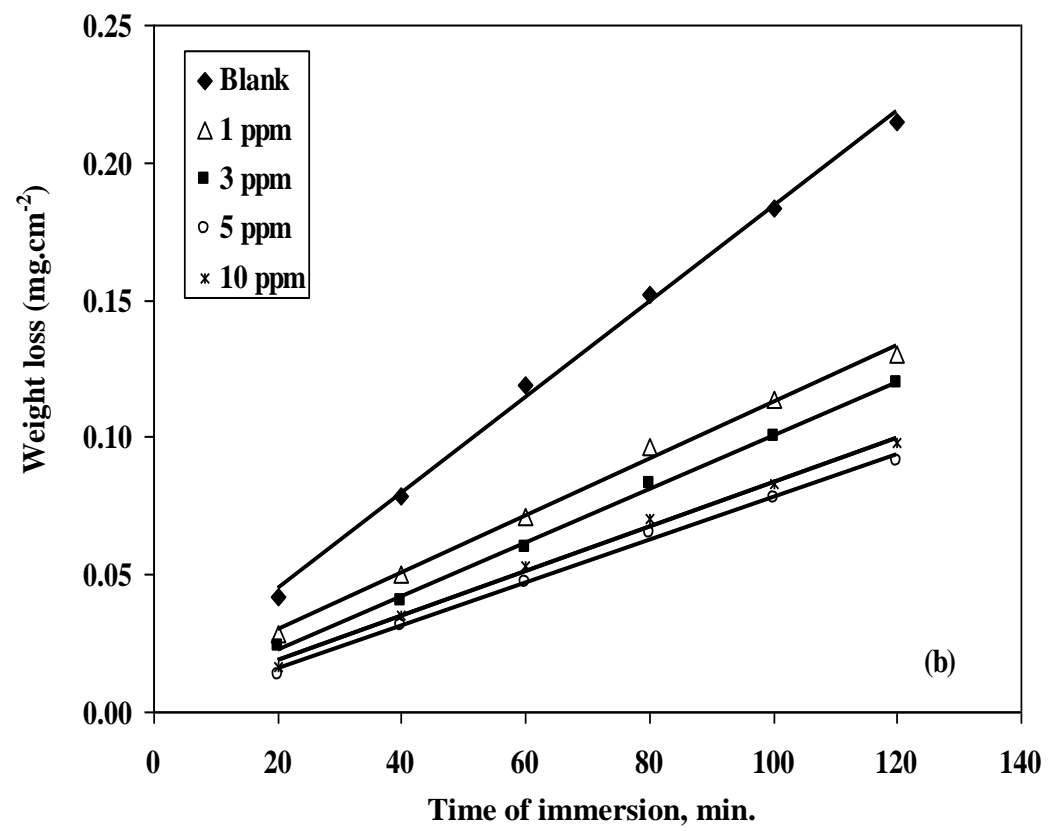

Fig.1. Weight loss vs. immersion time for aluminium in $0.5 \mathrm{M} \mathrm{HCl}$ solution in the absence and presence of different concentrations of monomeric surfactant $\mathrm{MC}_{6}(\mathrm{a})$ and its polymer $\mathrm{PC}_{6}(\mathrm{~b})$ at $30^{\circ} \mathrm{C}$. 
TABLE 3. Values of the inhibition efficiency and contact angle values of aluminum in $0.5 \mathrm{M} \mathrm{HCl}$ solution containing various concentrations of monomeric surfactant $\left(\mathrm{MC}_{6}\right)$ and its polymer $\left(\mathrm{PC}_{6}\right)$ at $30^{\circ} \mathrm{C}$.

\begin{tabular}{|c|c|c|c|c|c|c|}
\hline \multirow{3}{*}{$\begin{array}{l}\text { Concentration } \\
\text { (ppm) }\end{array}$} & \multicolumn{4}{|c|}{$\mathbf{P \%}$} & & \\
\hline & \multicolumn{2}{|c|}{$\begin{array}{l}\text { Weight loss } \\
\text { technique }\end{array}$} & \multicolumn{2}{|c|}{$\begin{array}{c}\text { Polarization } \\
\text { technique }\end{array}$} & \multicolumn{2}{|c|}{ Contact angle } \\
\hline & $\mathrm{MC}_{6}$ & $\mathrm{PC}_{6}$ & $\mathbf{M C}_{6}$ & $\mathrm{PC}_{6}$ & $\mathbf{M C}_{6}$ & $\mathrm{PC}_{6}$ \\
\hline 1 & 20.41 & 30.40 & 18.71 & 25.80 & 98.64 & 91.46 \\
\hline 3 & 24.53 & 44.70 & 25.72 & 41.97 & 93.25 & 69.8 \\
\hline 5 & 27.30 & 56.10 & 28.98 & 56.49 & 73.44 & 0.00 \\
\hline 10 & 31.14 & 49.70 & 32.26 & 49.82 & 68.63 & 12.10 \\
\hline
\end{tabular}

Figure 2 shows the influence of the temperature on weight loss for $\mathrm{Al}$ in $0.5 \mathrm{M}$ $\mathrm{HCl}$ in the absence and presence of $10 \mathrm{ppm}$ of $\mathrm{MC}_{6}$ and $\mathrm{PC}_{6}$. The data show that the weight loss and the corrosion rate of the $\mathrm{Al}$ sample increase with increasing temperature and the addition of both inhibitor surfactants retarded the rate of dissolution in all ranges of the investigated temperatures. This may be due to the decrease in the strength of adsorption process with increasing temperature; this suggested that physical adsorption may have been the type of adsorption of the inhibitor on $\mathrm{Al}$ surface. The corrosion rate (in $\mathrm{mg} \cdot \mathrm{cm}^{-2} \cdot \mathrm{min}^{-1}$ ) for each concentration of $\mathrm{MC}_{6}$ and $\mathrm{PC}_{6}$ (from $1 \mathrm{ppm}$ to $10 \mathrm{ppm}$ ) was calculated at different temperatures and the logarithm of the corrosion rate was plotted against the reciprocal of the absolute temperature $(1 / \mathrm{T})$ for each concentration according to Arrhenius equation ${ }^{(24,29)}$.

$$
\text { Logarithm of the corrosion rate }=\frac{- \text { Ea }}{2.303 \mathrm{RT}}+\mathrm{A}
$$

where $E_{a}$ is the apparent effective activation energy, $R$ is the universal gas constant and $\mathrm{A}$ is the Arrhenius pre-exponential factor. The corrosion rate for each concentration from 1 to $10 \mathrm{ppm}$ of the monomeric and its polymeric surfactant was calculated at different temperatures and the logarithm of the corrosion rate was plotted against $1 / \mathrm{T}$ for each concentration and the value of $\mathrm{E}_{\mathrm{a}}$ was calculated and tabulated in Table 4. An alternative formula of the Arrhenius equation is the transition state equation ${ }^{(24,29)}$.

$$
\text { Rate }=\frac{\mathbf{R T}}{\text { Nh }} \exp \frac{\Delta \mathbf{S}^{\circ}}{\mathbf{R}} \exp \left(-\frac{\Delta \mathbf{H}^{\mathrm{o}}}{\mathbf{R T}}\right)
$$



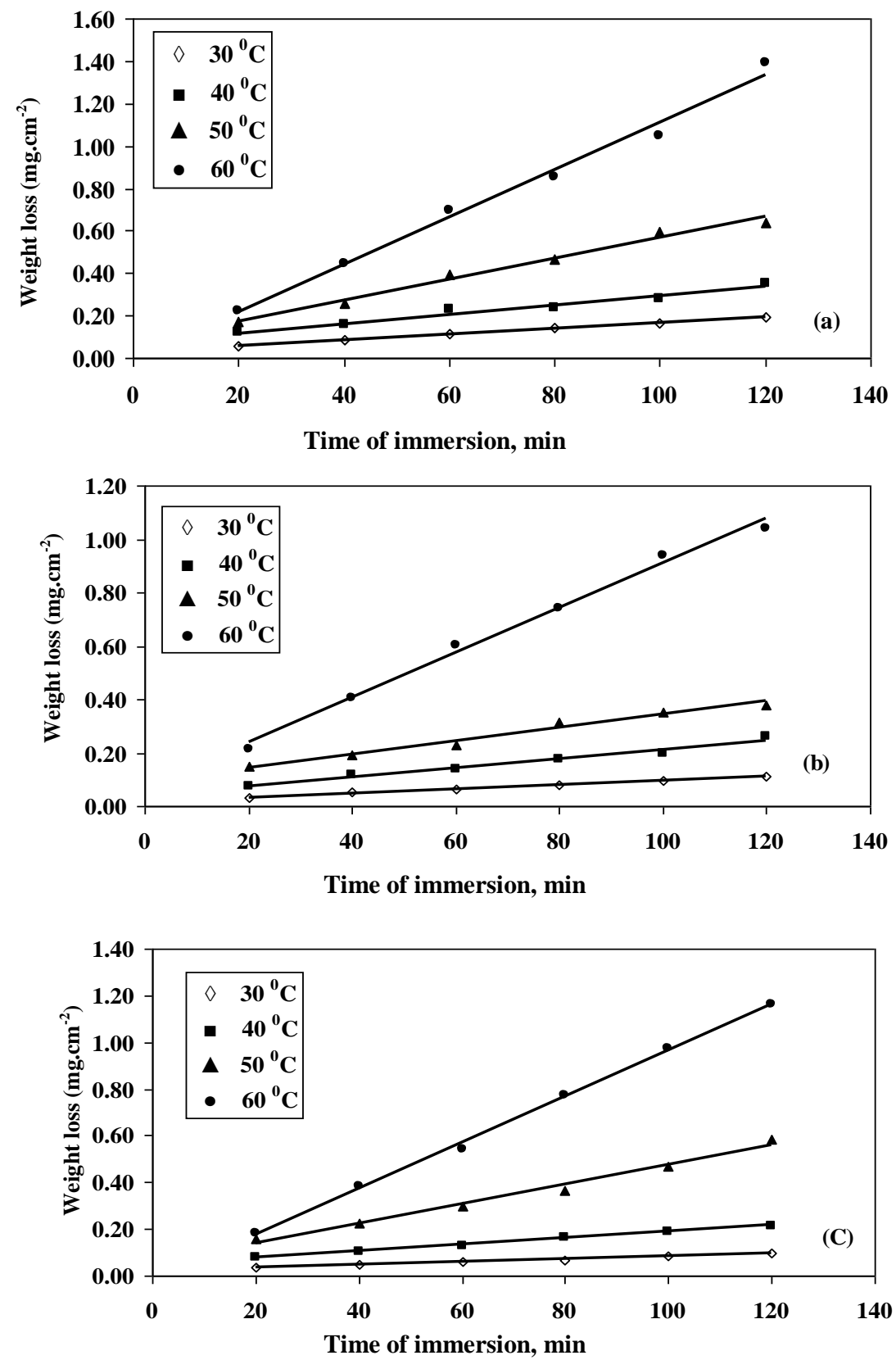

Fig. 2. Weight loss vs. immersion time for aluminium in $0.5 \mathrm{M} \mathrm{HCl}$ solution in the absence (a) and presence of $10 \mathrm{ppm}$ of monomeric surfactant $\mathrm{MC}_{6}(\mathrm{~b})$ and its polymer $\mathrm{PC}_{6}(\mathrm{C})$ at different temperatures. 
where $\mathrm{h}$ is the Planck's constant, $\mathrm{N}$ is the Avogadro 's number, $\Delta \mathrm{S}^{0}$ is the entropy of the activation, and $\Delta \mathrm{H}^{0}$ is the enthalpy of activation. The plot of log (Rate /T) vs. $1 / \mathrm{T}$ gives a straight line with a slope of $\left(-\Delta \mathrm{H}^{0} / 2.303 \mathrm{R}\right)$, from which the value of $\Delta \mathrm{H}^{0}$ was calculated and listed in Table 4 . The data in Table 4 reveal that the addition of both surfactant inhibitors enhanced the values of both $\mathrm{E}_{\mathrm{a}}$ and $\Delta \mathrm{H}^{0}$. The enhancement may have been due to the adsorption of surfactant inhibitors on the $\mathrm{Al}$ surface and increased the energy barrier of the corrosion reaction as the concentrations of the inhibitors increased. This suggests that the process was activation-controlled. The activation energy value of $78.1 \mathrm{kJmol}^{-1}$ for the $\mathrm{HCl}$ inhibitor systems suggested the fact that the inhibitors were physically adsorbed on the $\mathrm{Al}$ surface which was in agreement with the same earlier reports ${ }^{(30-33)}$.

TABLE 4. Effect of monomeric surfactant $\left(\mathrm{MC}_{6}\right)$ and its polymer $\left(\mathrm{PC}_{6}\right)$ concentrations on the thermodynamics dissolution process of $\mathrm{Al}$ in 0.5 M HCl solution (obtained from weight loss and polarization techniques).

\begin{tabular}{|c|c|c|c|c|c|c|c|c|}
\hline \multirow{3}{*}{$\begin{array}{c}\text { Conc. } \\
\text { ppm }\end{array}$} & \multicolumn{4}{|c|}{$\mathrm{E}_{\mathrm{a}} \mathrm{kJmol}^{-1}$} & \multicolumn{4}{|c|}{$\Delta \mathbf{H}^{0} \mathrm{kJmol}^{-1}$} \\
\hline & \multicolumn{2}{|c|}{$\begin{array}{l}\text { Weight loss } \\
\text { technique }\end{array}$} & \multicolumn{2}{|c|}{$\begin{array}{c}\text { Polarization } \\
\text { technique }\end{array}$} & \multicolumn{2}{|c|}{$\begin{array}{l}\text { Weight loss } \\
\text { technique }\end{array}$} & \multicolumn{2}{|c|}{$\begin{array}{c}\text { Polarization } \\
\text { technique }\end{array}$} \\
\hline & $\mathrm{MC}_{6}$ & $\mathrm{PC}_{6}$ & $\mathrm{MC}_{6}$ & $\mathbf{P C}_{6}$ & $\mathrm{MC}_{6}$ & $\mathrm{PC}_{6}$ & $\mathrm{MC}_{6}$ & $\mathrm{PC}_{6}$ \\
\hline Blank & 57.4 & 57.4 & 57.3 & 57.3 & 55.5 & 55.5 & 54.7 & 54.7 \\
\hline 1 & 61.6 & 63.5 & 63.2 & 64 & 57.9 & 62.1 & 60.6 & 61.3 \\
\hline 3 & 64.2 & 69.4 & 65.7 & 71 & 62.8 & 69.3 & 63.2 & 68.4 \\
\hline 5 & 67.2 & 80.6 & 66.8 & 78.2 & 64.5 & 77.6 & 64.1 & 75.6 \\
\hline 10 & 69.1 & 77.7 & 68.2 & 75.1 & 68.3 & 75.8 & 65.5 & 72.4 \\
\hline
\end{tabular}

Potentiodynamic polarization measurements

Figure 3 shows the effect of different concentrations of $\mathrm{MC}_{6}$ and $\mathrm{PC}_{6}$ on the potentiodynamic cathodic and anodic polarization curves for $\mathrm{Al}$ in $0.5 \mathrm{M} \mathrm{HCl}$ solution with scan rate of $25 \mathrm{mVS}^{-1}$ at $30^{\circ} \mathrm{C}$ in the absence and presence of different concentrations of monomeric surfactant $\mathrm{MC}_{6}$ and its polymer $\mathrm{PC}_{6}$ where as Fig. 4 illustrates the influence of temperature on the potentiodynamic cathodic and anodic polarization curves of $\mathrm{Al}$ in $0.5 \mathrm{M} \mathrm{HCl}$ containing $10 \mathrm{ppm}$ of both $\mathrm{MC}_{6}$ and $\mathrm{PC}_{6}$. The data clearly show that the addition of $\mathrm{MC}_{6}$ and $\mathrm{PC}_{6}$ enhanced both the anodic and cathodic overpotential and decreased the corresponding potential anodic (dissolution of the metal) and potential cathodic (evolution of hydrogen) current densities. The addition of each inhibitor decreased the values of $I_{\text {corr }}$ (corrosion current), this confirmed the inhibition of the corrosion process. Moreover, the corrosion potential was displayed to more positive values in the presence of the inhibitor; this revealed that these surfactants predominantly acted as anodic inhibitors.

Egypt. J. Chem. 55, No.6 (2012) 

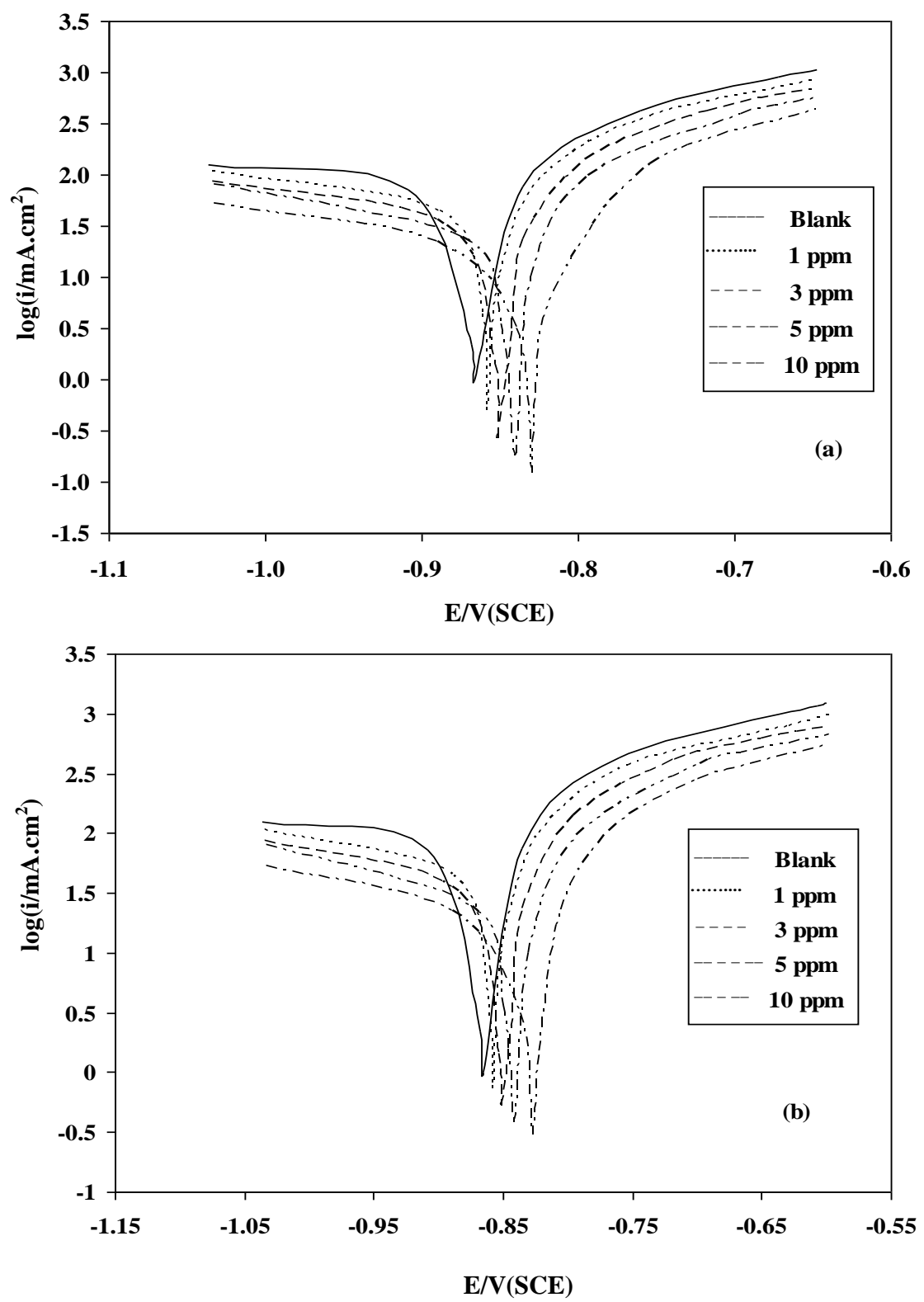

Fig. 3. Effect of $\mathrm{MC}_{6}(\mathrm{a})$ and $\mathrm{PC}_{6}$ (b) concentrations on the cathodic and anodic polarization of aluminium in $0.5 \mathrm{M} \mathrm{HCl}$ solution with a scan rate of $25 \mathrm{mVs}^{-1}$ at $30{ }^{\circ} \mathrm{C}$. 

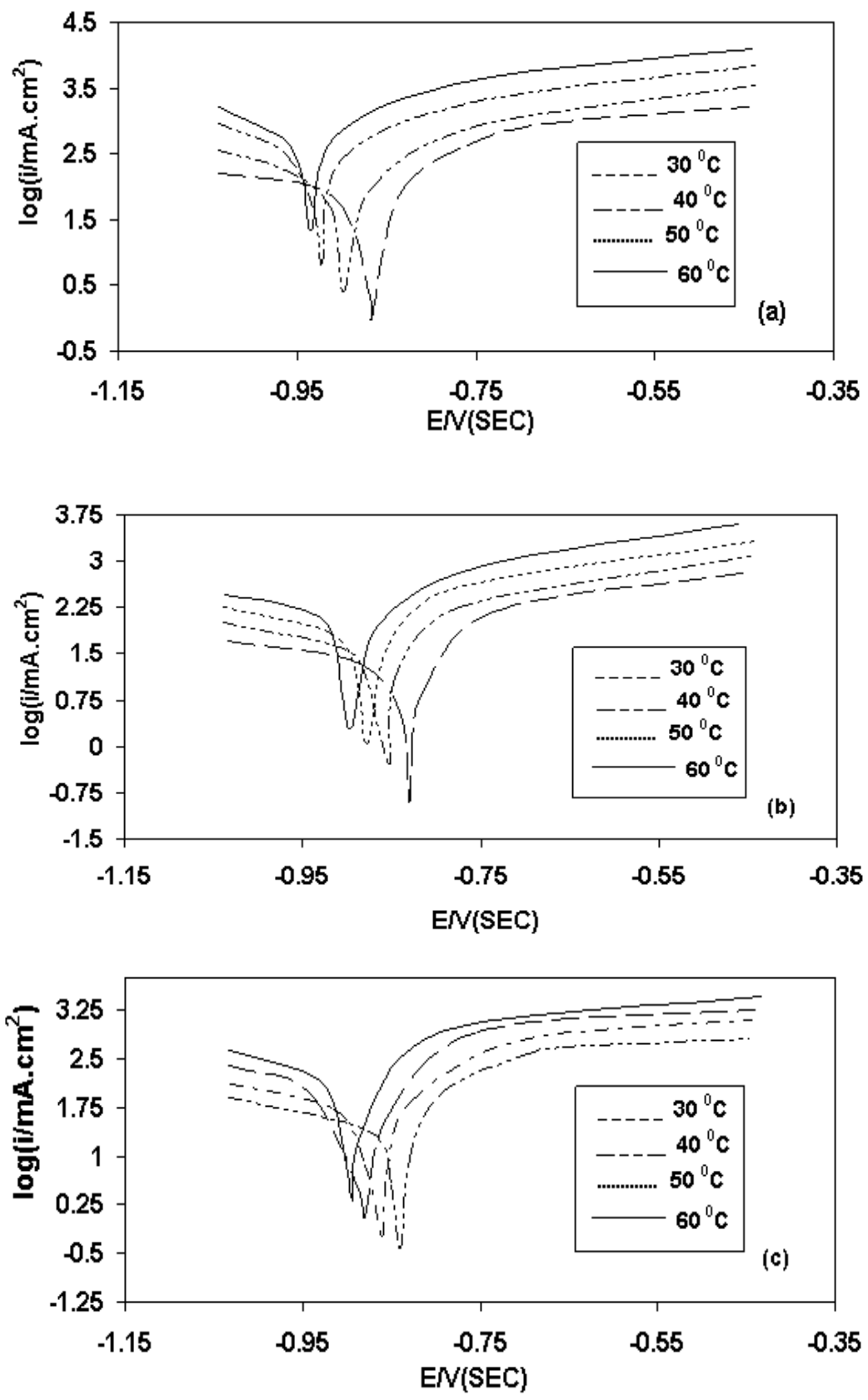

Fig. 4. Effect of temperature on the cathodic and anodic polarization of aluminum in $0.5 \mathrm{MHCl}$ in the absence(a), presence $10 \mathrm{ppm}$ of $\mathrm{MC}_{6}(\mathrm{~b})$ and $10 \mathrm{ppm}$ of $\mathrm{PC}_{6}(\mathrm{c})$ with a scan rate $25 \mathrm{mVs}^{-1}$.

Egypt. J. Chem. 55, No.6 (2012) 
The electrochemical parameter $1_{\text {corr }}, E_{\text {corr }}$, the corrosion potentials $\left(b_{c}\right)$ and $\left(b_{a}\right)$ are cathodic and anodic Tafel slope respectively and the corrosion rate associated with the corrosion of $\mathrm{Al}$ in the absence and presence of different concentrations of $\mathrm{MC}_{6}$ and $\mathrm{PC}_{6}$ at different temperatures are listed in Tables $5 \& 6$. The corrosion rate is directly related to the corrosion current density $1_{\text {corr }}$, inhibition efficiency (P\%) at different inhibitor concentrations and temperatures were calculated from the equation ${ }^{(5)}$ :

$$
\mathbf{P} \%=100 x\left(1-\frac{\left(\mathbf{I}_{\text {corr }}\right)_{I}}{\left(I_{\text {corr }}\right)_{0}}\right)
$$

and the data are given in the Table 3 , where $\left(1_{\text {corr }}\right)_{0}$ and $\left(1_{\text {corr }}\right)_{I}$ are the corrosion current densities in the absence and presence of inhibitor surfactants . It is seen that, the inhibition efficiency increases with the increase of the surfactant concentration up to the critical concentrations. However, the inhibition efficiency decreased with raising the temperature. The slopes of the anodic $\left(b_{a}\right)$ and cathodic $\left(b_{c}\right)$ Tafel lines are approximately equal. These results indicate that these inhibitors act by simply blocking the available surface area for corrosion reaction. In other words, the inhibitor decreases the surface area for corrosion without affecting the mechanism of corrosion reaction and only causes inactivation of a part of the aluminium surface with respect to the corrosive medium.

TABLE 5. The electrochemical parameters associated with polarization measurements for $\mathrm{Al}$ in $0.5 \mathrm{M} \mathrm{HCl}$ solution in the absence and presence of different concentrations of monomeric surfactant $\left(\mathrm{MC}_{6}\right)$ and its polymer $\left(\mathrm{PC}_{6}\right)$ at $30^{\circ} \mathrm{C}$.

\begin{tabular}{|c|c|c|c|c|c|c|c|c|}
\hline \multirow{2}{*}{$\begin{array}{l}\text { Conc. } \\
\text { (ppm) }\end{array}$} & \multicolumn{4}{|c|}{$\mathrm{MC}_{6}$} & \multicolumn{4}{|c|}{$\mathrm{PC}_{6}$} \\
\hline & $\begin{array}{l}E_{\text {corr }} \\
(\mathrm{mV})\end{array}$ & $\begin{array}{c}I_{\text {corr }} \\
\left(\mu \mathrm{A} \cdot \mathrm{cm}^{-2}\right)\end{array}$ & $\begin{array}{c}\text { ba } \\
\left(\mathrm{mV}^{-} \text {dec }^{-1}\right)\end{array}$ & $\begin{array}{c}\text {-bc } \\
\left(\mathbf{m V} \cdot \text { dec }^{-1}\right)\end{array}$ & $\begin{array}{r}E_{\text {corr }} \\
(\mathbf{m V})\end{array}$ & $\begin{array}{c}I_{\text {corr }} \\
\left(\mu \mathrm{A} \cdot \mathrm{cm}^{-2}\right)\end{array}$ & $\begin{array}{c}\text { ba } \\
\left(\mathrm{mV} \cdot \mathrm{dec}^{-1}\right)\end{array}$ & $\begin{array}{c}\text {-bc } \\
\left(\mathrm{mV} \cdot \mathrm{dec}^{-1}\right)\end{array}$ \\
\hline Blank & -0.82 & 95.22 & 0.044 & 0.35 & -0.82 & 95.22 & 0.044 & 0.34 \\
\hline 1 & -0.721 & 77.41 & 0.109 & 0.35 & -0.67 & 70.67 & 0.240 & 0.34 \\
\hline 3 & -0.71 & 69.70 & 0.121 & 0.35 & -0.76 & 55.25 & 0.057 & 0.36 \\
\hline 5 & -0.82 & 67.62 & 0.103 & 0.27 & -0.66 & 41.43 & 0.285 & 0.38 \\
\hline 10 & -0.75 & 64.50 & 0.084 & 0.32 & -0.96 & 44.22 & 0.215 & 0.31 \\
\hline 15 & -0.69 & 63.64 & 0.310 & 0.32 & -0.69 & 47.19 & 0.115 & 0.35 \\
\hline 20 & -0.72 & 56.60 & 0.137 & 0.31 & -0.71 & 48.72 & 0.141 & 0.38 \\
\hline 25 & -0.81 & 54.11 & 0.106 & 0.31 & -0.71 & 47.72 & 0.074 & 0.37 \\
\hline 30 & -0.74 & 72.09 & 0.131 & 0.31 & -0.72 & 49.10 & 0.140 & 0.35 \\
\hline 40 & -0.79 & 77.91 & 0.044 & 0.43 & -0.714 & 48.67 & 0.091 & 0.38 \\
\hline
\end{tabular}

TABLE 6. The electrochemical parameters associated with polarization measurements for $\mathrm{Al}$ in $0.5 \mathrm{M} \mathrm{HCl}$ solution in the presence of $10 \mathrm{ppm}$ of monomeric surfactant $\left(\mathbf{M C}_{6}\right)$ and its polymer $\left(\mathbf{P C}_{6}\right)$ at different temperatures.

\begin{tabular}{|c|c|c|c|c|c|c|c|c|}
\hline \multirow[b]{2}{*}{$\mathbf{T}(\mathbf{k})$} & \multicolumn{4}{|c|}{$\mathrm{MC}_{6}$} & \multicolumn{4}{|c|}{$\mathrm{PC}_{6}$} \\
\hline & $\begin{array}{c}\mathbf{E}_{\text {corr }} \\
(\mathbf{m V})\end{array}$ & $\begin{array}{c}\mathbf{I}_{\text {corr }} \\
\left(\mu \mathrm{A} . \mathrm{cm}^{-2}\right)\end{array}$ & $\begin{array}{c}\text { ba } \\
\left(\mathbf{m V} \cdot \operatorname{dec}^{-1}\right)\end{array}$ & $\begin{array}{c}\text {-bc } \\
\left(\mathrm{mV} \cdot \operatorname{dec}^{-1}\right)\end{array}$ & $\begin{array}{l}\mathbf{E}_{\text {corr }} \\
(\mathbf{m V})\end{array}$ & $\begin{array}{c}\mathbf{I}_{\text {corr }} \\
\left(\mu \mathrm{A} \cdot \mathrm{cm}^{-2}\right)\end{array}$ & $\begin{array}{c}\text { ba } \\
\left.\left(\mathrm{mV}^{-d_{e c}}\right)^{-1}\right)\end{array}$ & $\begin{array}{c}\text {-bc } \\
\left(\mathrm{mV} \cdot \mathrm{dec}^{-1}\right)\end{array}$ \\
\hline 303 & -0.75 & 64.51 & 0.084 & 0.319 & -0.96 & 44.22 & 0.215 & 0.310 \\
\hline 313 & -1.01 & 256.33 & -0.560 & 0.102 & -0.90 & 202.00 & -0.460 & 0.091 \\
\hline 323 & -0.97 & 518.24 & -0.366 & 0.123 & -0.899 & 417.21 & -0.441 & 0.082 \\
\hline 333 & -0.97 & 771.80 & -0.540 & 0.096 & -1.22 & 704.32 & -0.371 & 0.187 \\
\hline
\end{tabular}




\section{Adsorption isotherm}

To get more information about the mode of adsorption of the inhibitors on the Al surface at different temperatures, the obtained data from the two different techniques were tested with several adsorption isotherms "Langmuir"adsorption isotherm was found to fit well with our experimental data. Figure 5 represents curve fitting of $\mathrm{MC}_{6}$ monomeric surfactant and its analogues polymer $\mathrm{PC}_{6}$ using data obtained from potentiodynamic polarization measurements. Similar results were obtained from weight loss technique. The adsorption isotherm relationship of Langmuir is represented by the following equation ${ }^{(31)}$ :

$$
\frac{\mathbf{C}_{\mathbf{i}}}{\Theta}=\frac{1}{\left(\mathbf{K}_{\mathrm{ads}}\right)}+\mathbf{C}_{\mathbf{i}}
$$

where $C_{i}$ is the concentration of the inhibitor in bulk solution, $\theta$ is the surface coverage $(\theta=\mathrm{P} / 100)$ inhibition efficiency and $\mathrm{K}_{\mathrm{ads}}$ is the adsorption equilibrium constant.

Frumkin $^{(32)}$ isotherm was also found to fit well with the obtained experimental data. The adsorption isotherm relationship of Frumkin is represented by the following equation:

$$
\ln \frac{\theta}{\mathbf{C}_{\mathbf{i}}}(1-\theta)=\ln \mathrm{K}_{\mathrm{ads}}+2 \mathrm{a} \theta
$$

where (a) is the lateral interaction term describing the molecular interactions in the adsorption layer and the heterogeneity of the surface and measure for the steepness of the adsorption isotherm. The more positive the value of (a) is the steeper the adsorption isotherm. Curves fitting of the weight loss data for $\mathrm{MC}_{6}$ and $\mathrm{PC}_{6}$ are graphically represented in Fig. 6. Similar results were obtained from the data of the potentiodynamic technique.

The adsorption thermodynamic parameters $\left(\Delta \mathrm{H}_{\mathrm{ads}}\right.$ and $\left.\Delta \mathrm{S}_{\mathrm{ads}}\right)$ for the surfactant adsorption on $\mathrm{Al}$ surface in $0.5 \mathrm{M} \mathrm{HCl}$ at different temperatures were determined from the slopes and intercepts of the lines of $\log \mathrm{K}_{\mathrm{ads}}$ vs. 1/T plots with the following equation ${ }^{(31)}$ :

$$
\log \mathbf{K}_{\mathrm{ads}}=-\frac{\Delta \mathbf{H}_{\mathrm{ads}}}{2.303 \mathrm{RT}}+\frac{\Delta \mathbf{S}_{\mathrm{ads}}}{2.303 \mathbf{R}}
$$

where $\Delta \mathrm{H}_{\mathrm{ads}}$ and $\Delta \mathrm{S}_{\mathrm{ads}}$ are the enthalpy and entropy of the adsorption process, respectively. The calculated values for $\Delta \mathrm{H}_{\mathrm{ads}}, \Delta \mathrm{S}_{\mathrm{ads}}$ and $\Delta \mathrm{G}_{\mathrm{ads}}$ are listed in Table 7 $\left(\Delta \mathrm{G}_{\mathrm{ads}}=\Delta \mathrm{H}_{\mathrm{ads}}-\mathrm{T} \Delta \mathrm{S}_{\mathrm{ads}}\right)$. The thermodynamic functions of the adsorption process obtained from the two techniques confirm each other. The calculated values of $\Delta \mathrm{G}_{\text {ads }}$ were low suggesting that the nature of the inhibitor adsorption was mainly physical adsorption and their negative sign indicated spontaneous interaction of the inhibitor with aluminium surface ${ }^{(33,34)}$. The negative value of $\Delta \mathrm{H}_{\text {ads }}$ indicated that the adsorption of the inhibitors on Al surface was an exothermic process. The values of $\Delta \mathrm{H}_{\mathrm{ads}}$ and $\Delta \mathrm{S}_{\mathrm{ads}}$ were characteristic of the occurrence of a replacement process between the inhibitor species and adsorbed water molecules from the surface of metal during the adsorption of the inhibitor compound on the metal surface ${ }^{(35)}$.

Egypt. J. Chem. 55, No.6 (2012) 

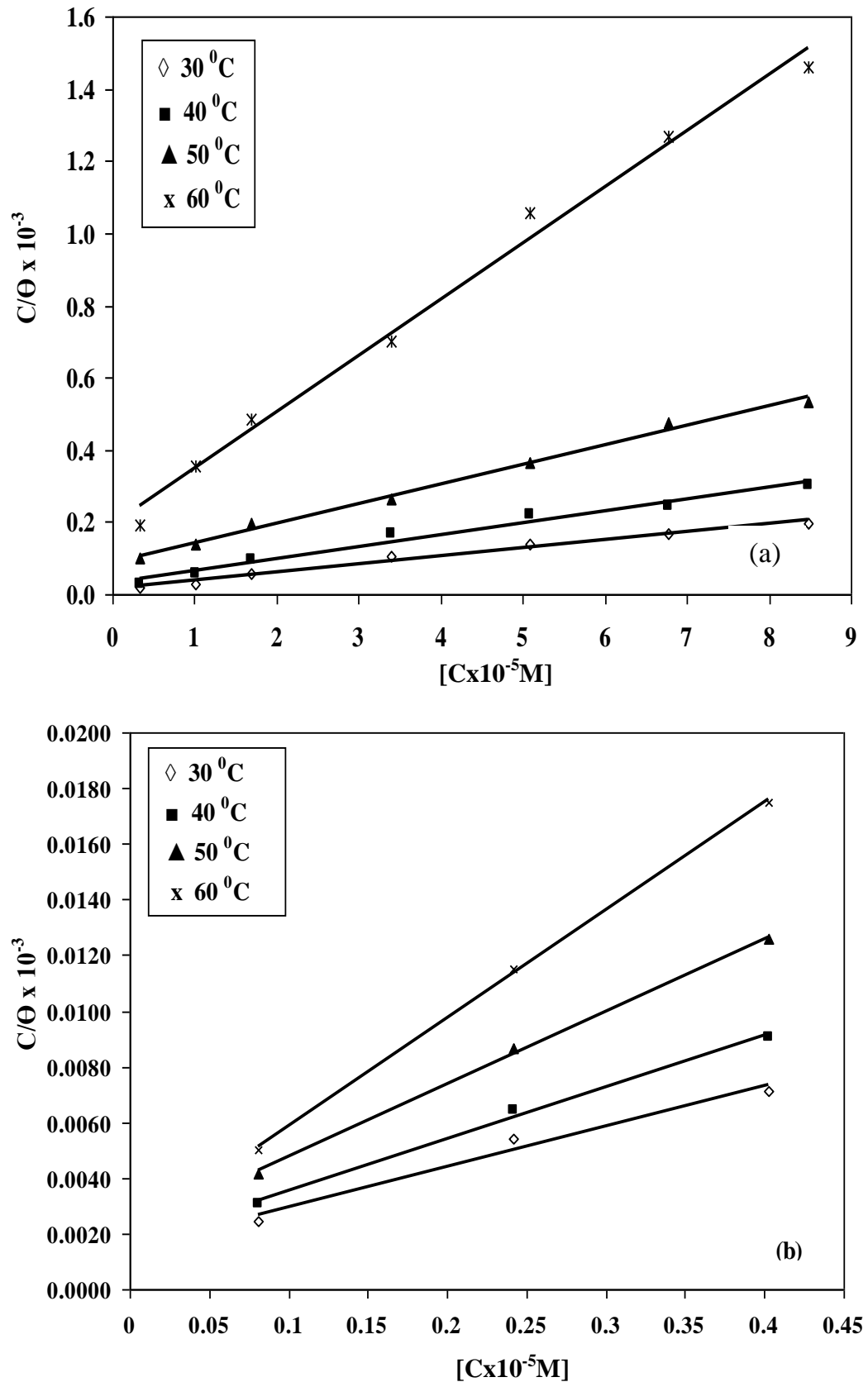

Fig. 5. Langmuir adsorption isotherm of $\mathrm{MC}_{6}$ (a) and $\mathrm{PC}_{6}(\mathrm{~b})$ using potentiodynamic polarization data at different temperatures. 

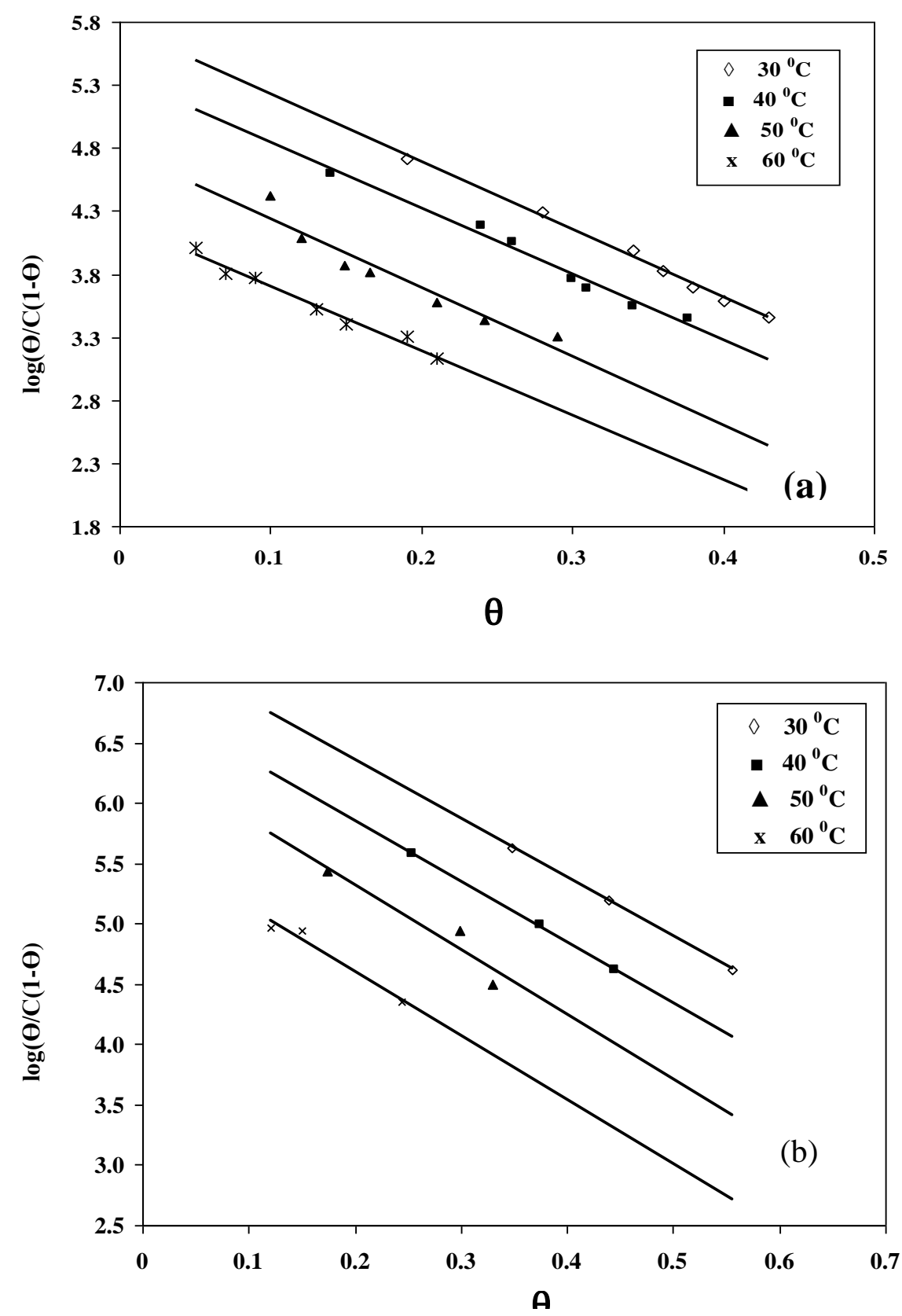

Fig.6. Curve fitting of weight loss data of $\mathrm{Al}$ in $0.5 \mathrm{M} \mathrm{HCl}$ solution containing various concentrations of $\mathrm{MC}_{6}(\mathrm{a})$ and $\mathrm{PC}_{6}$ (b) to Frumkin isotherm at different temperatures.

Egypt. J. Chem. 55, No.6 (2012) 
TABLE 7. The thermodynamic parameter of adsorption process obtained by applying Frumkin model and Gibbs equation $\left(\Delta \mathrm{G}_{\mathrm{ads}}=\Delta \mathrm{H}_{\mathrm{ads}}-\mathrm{T} \Delta \mathrm{S}_{\mathrm{ads}}\right)$ on the weight loss and polarization data of $\mathrm{Al}$ in $0.5 \mathrm{M} \mathrm{HCl}$ in the $30-60{ }^{\circ} \mathrm{C}$ temperature range.

\begin{tabular}{ccccccc}
\hline \multirow{2}{*}{$\begin{array}{c}\text { Technique } \\
\text { used }\end{array}$} & \multicolumn{2}{c}{ Monomeric surfactant } & \multicolumn{2}{c}{ Polymeric surfactant } \\
\cline { 2 - 7 } & $\begin{array}{c}\Delta \mathbf{H}_{\text {ads }} \\
\mathbf{k J m o l}^{-1}\end{array}$ & $\begin{array}{c}\Delta \mathbf{S}_{\text {ads }} \\
\mathbf{k J m o l}^{-1}\end{array}$ & $\begin{array}{c}-\Delta \mathbf{G}_{\text {ads }} \\
\mathbf{k J m o l}^{\mathbf{1}}\end{array}$ & $\begin{array}{c}\Delta \mathbf{H}_{\text {ads }} \\
\mathbf{k J m o l}^{\mathbf{1}}\end{array}$ & $\begin{array}{c}\Delta \mathbf{S}_{\text {ads }} \\
\mathbf{k J m o l}^{\mathbf{1}}\end{array}$ & $\begin{array}{c}-\Delta \mathbf{G}_{\text {ads }} \\
\mathbf{k J m o l}^{\mathbf{1}}\end{array}$ \\
\hline Weight loss & -104.54 & -0.2202 & 35.92 & -42.12 & -0.0210 & 35.73 \\
Polarization & -103.39 & -0.2220 & 37.83 & -44.03 & -0.0216 & 37.48 \\
\hline
\end{tabular}

\section{Conclusion}

- The addition of $\mathrm{MC}_{6}$ and $\mathrm{PC}_{6}$ surfactants inhibits the corrosion of aluminium in $0.5 \mathrm{M} \mathrm{HCl}$ solution.

- The inhibition efficiency of polymeric surfactant was higher than that of monomeric surfactant.

- The inhibition efficiency of the two surfactants increases with the increase of inhibitor concentration but decreases with the increase of temperature.

- The data obtained from weight loss and potentiodynamic polarization techniques were in good agreement with each other and fit well with the Langmuir and Frumkin isotherms.

\section{References}

1. Sorkhabi, H. A., Ghasemi, Z. and Seifzadeh, D., The inhibition effect of some amino acids towards the corrosion of aluminium in $1 \mathrm{M} \mathrm{HCl}+1 \mathrm{M} \mathrm{H}_{2} \mathrm{SO}_{4}$ solution. Appl. Suf. Sci. 247, 408 (2005).

2. Retnnagiri, V., Jeyaprakash, P., Arunkumar, M., Maheswaran, V. and Madhiyalagan, A., Investigation and inhibition of aluminium corrosion in hydrochloric acid solutions by organic compound. Advances in Applied Science Research, 31,718 (2012).

3. Dalmoro, V., dos Santos, J. H.Z., Armelin, E., Alemán, C. and Azambuja, D.S., A synergistic combination of tetraethylorthosilicate and multiphosphonic acid offers excellent corrosion protection to AA1100 aluminium alloy. Appl. Sur. Sci. (2013).

4. Abd El Haleem, S.M., Abd El Wanees, S., Abd El Aal, E.E. and Farouk., A., Factors affecting the corrosion behaviour of aluminium in acid solutions. I. Nitrogen and/or sulphur-containing organic compounds as corrosion inhibitors for $\mathrm{Al}$ in $\mathrm{HCl}$ solutions. Corros. Sci. 68, 1 (2013).

5. Abd El Rehim, S.S., Hassan, H.H. and Amin., M.A., The corrosion inhibition study of sodium dodecyl benzene sulphonate to aluminium and its alloys in $1.0 \mathrm{M} \mathrm{HCl}$ solution. Mater. Chem. and Phys. 78, 337 (2003). 
6. Zhao,T. and Mu, G., The adsorption and corrosion inhibition of anion surfactants on aluminium surface in hydrochloric acid . Corros. Sci. 41, 1937 (1999).

7. Amin, M.A., Abd El-Rehim, S.S., El-Sherbini, E.E., Hazzazi, O.A. and Abbas, M.N., Polyacrylic acid as a corrosion inhibitor for aluminium in weakly alkaline solutions. Part I: Weight loss, polarization, impedance EFM and EDX studies. Corros. Sci., 51, 658 (2009)

8. Breslin, C., Fenelon, A. and Conroy, K., Surface engineering: Corrosion protection using conducting polymers. Material and Design , 26, 233 (2005).

9. Wang, Y., Li, Y. and Wang, F., Polymeric organo-silane coatings for aluminium alloy corrosion protection by self-assembled method. E-Journal of Chemistry, 9, 435(2012)

10. He, J., Gelling, V.J., Tallman, D.E., Bierwagen, G.P. and Wallace, G.G., Conducting polymers and corrosion III. A scanning vibrating electrode study of poly(3-octyl pyrrole) on steel and aluminium. J. Electr. Soci, 147, 3667 (2000).

11. Gonzalez-Rodriguez, J.G., Lucio-Garc'ıa , M.A., Nicho, M.E., Cruz-Silva , R., Casales, M. and Valenzuela, E., Improvement on the corrosion protection of conductive polymers in pemfc environments by adhesives. Journal of Power Sources, 168,184 (2007).

12. Joseph, S., McClure, J.C., Sebastian , P.J., Moreira, J. and Valenzuela, E., Polyaniline and polypyrrole coatings on aluminium for PEM fuel cell bipolar plates. Journal of Power Sources, 177, 161 (2008) .

13. Lee, C., Lee, Y., Kim, K., Jeong, M. and Lim, D., Electrically conductive polymer composite coating on aluminium for PEM fuel cells bipolar plate. Renewable Energy, 54 (2013).

14. Johansen, H.D., Brett, C.M.A. and Motheo, A.J., Corrosion protection of aluminium alloy by cerium conversion and conducting polymer duplex coatings. Corros. Sci. 63, 342 (2012).

15. Zubillaga, O., Cano, F.J., Azkarate, I., Molchan, I.S., Thompson, G.E., Cabral, A.M. and Morais, P.J., Corrosion performance of anodic films containing polyaniline and $\mathrm{TiO}_{2}$ nanoparticles on AA3105 aluminium alloy. Surface \& Coatings Technology, 202, 5936 (2008) .

16. Bereket, G. and Yurt, A., The inhibition effect of amino acids and hydroxy carboxylic acids on pitting corrosion of aluminium alloy 7075. Corros. Sci. 43, 1179(2001).

17. Yurt, A., Bereket, G. and Ogretir, C., Quantum chemical studies on inhibition effect of amino acids and hydroxy carboxylic acids on pitting corrosion of aluminium alloy 7075 in $\mathrm{NaCl}$ solution. Journal of Molecular Structure: Theochem . 725, 215 (2005). 
18. Foad El-Sherbini, E.E., Abd-El-Wahab, S.M. and Deyab, M.A., Studies on corrosion inhibition of aluminium in $1.0 \mathrm{M} \mathrm{HCl}$ and $1.0 \mathrm{M} \mathrm{H}_{2} \mathrm{SO}_{4}$ solutions by ethoxylated fatty acids. Mater. Chem. and Phys. 82, 631( 2003) .

19. Maitra, A. and Barua, S., Dicyandiamide an inhibitor for acid corrosion of pure aluminium. Corros. Sci. 14, 587 (1974).

20. Zheludkevich, M.L., Yasakau K.A., Poznyak, S.K. and Ferreira, M.G.S., Triazole and thiazole derivatives as corrosion inhibitors for AA2024 aluminium alloy. Corro. Sci. 47, 3368 (2005)

21. Sherif, M. El-Sayed, Electrochemical investigations on the corrosion inhibition of aluminium by 3-amino-1,2,4-triazole-5-thiol in naturally aerated stagnant seawater. Journal of Industrial and Engineering Chemistry (2013).

22. Edrah, S. and Hasan, S.K., Studies on thiourea derivatives as corrosion inhibitor for aluminium in sodium hydroxide solution. J. Appl. Sci., 6, 1045 (2010).

23. Uwah, I.E., Okafor, P.C. and Ebiekpe, V.E., Inhibitive action of ethanol extracts from Nauclea latifolia on the corrosion of mild steel in $\mathrm{H}_{2} \mathrm{SO}_{4}$ solutions and their adsorption characteristics. Arab.J. Chem. (2010).

24. Abd El Rehim, S.S., Hassan, H.H. and Amin, M.A., The corrosion inhibition study of sodium dodecyl benzene sulphonate to aluminium and its alloys in $1.0 \mathrm{M}$ HCl solution. Mater. Chem. and Phys. 78, 337 (2003).

25. Sayyah , S.M., Abd El-Salam, H.M. and Azzam, E.M.S., Surface activity of monomeric and polymeric (3-alkyloxy aniline) surfactants. Inter. J. Polymeric Materials, 54, 541 (2005).

26. Sayyah, S.M. Azzam, E. M.S., Khalil, A. B. and Mohamed, S.M., Improvement of the surface activity and the solubility for some synthesized polyaniline surfactants. Egypt. J.Chem. 55 (6), 561-581 (2012).

27. Silversyein, R.M., Bassler, C.G. and Morill, T.C., Spectroscopic Identification of Organic Compounds; Willey, New York (1974).

28. Osman, M.M. and Abd El Rehim, S.S., The effect of some ethoxylated fatty acids on corrosion of aluminium in hydrochloric acid solutions. Mater. Chem. and Phy, 53, 34 (1998).

29. Abd El Rehim, S.S., Sayyah, S.M., El-Deeb, M.M., Kamal, S.M. and Azooz, R.E., Poly(o-phenylenediamine) as an inhibitor of mild steel corrosion in $\mathrm{HCl}$ solution. Mater. Chem. and Phys. 123, 20 (2010).

30. Khedr , M.G. and Lashien, M.S., Corros. Sci. 33, 137 (1992).

31. Alinnor, I.J. and Ejikeme, P.M., Corrosion inhibition of aluminium in acidic medium by different extracts of ocimum gratissimum. American Chemical Science Journal, 2, 122 (2012). 
32. Jevremović, I. and Stanković, V.M., The inhibitive effect of ethanolamine on corrosion behavior of aluminium in $\mathrm{NaCl}$ solution saturated with $\mathrm{CO}_{2}$. Metall. Mater. Eng. 18, 241 (2012).

33. Oguzie, E.E., Corrosion inhibition of aluminium in acidic and alkaline media by Sansevieria trifasciata extract. Corros. Sci. 49, 1527(2007).

34. Fouda, A.S., Al-Sarawy, A.A., Ahmed, F.Sh. and El-Abbasy, H.M., Corrosion inhibition of aluminium 6063 using some pharmaceutical compounds. Corros. Sci. 51, 485(2009).

35. Iampinen, M.J. and Fomino, M., J. Electrochem. Soc. 140, 3537 (1993).

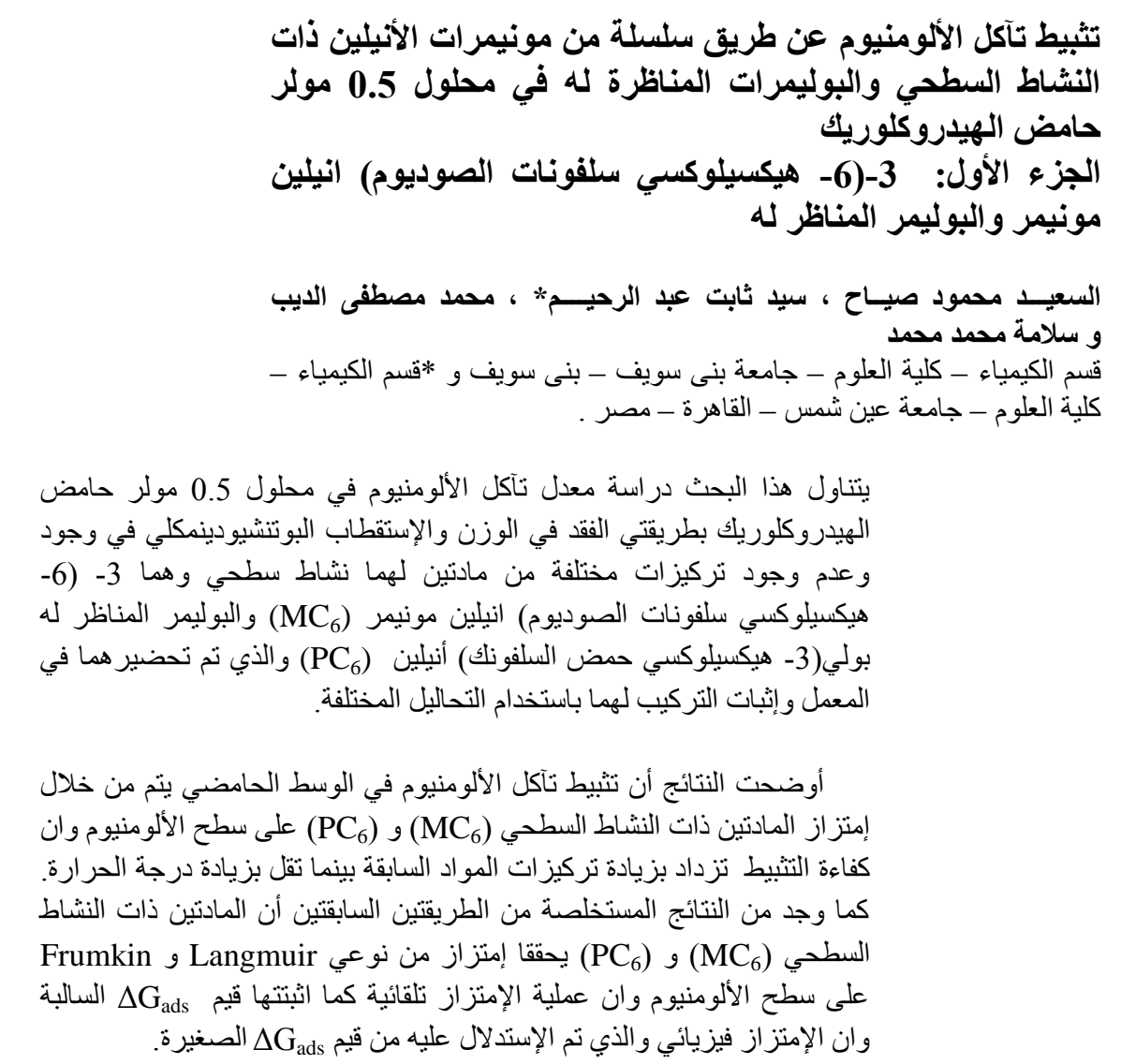

Egypt. J. Chem. 55, No.6 (2012) 